\title{
Polska emigracja w Wielkiej Brytanii - trudne początki edukacji narodowej na obczyźnie
}

\author{
Polish emigration in Great Britain - difficult beginnings \\ of education abroad
}

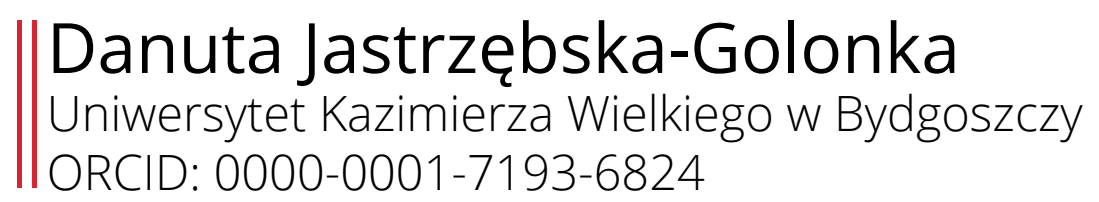

\begin{abstract}
The subject of the article is the second Polish emigration in Great Britain and the national upbringing of the young generation: familiarization with Polish traditions, Polish history and the idea of independence. The purpose of the emigrants was to organize Polish schools in which children would learn Polish culture, language and literature. However, the idea faced many difficulties, such as combining education in Polish and English schools, poor housing conditions, the lack of Polish textbooks, the influence of English, the shame of their language and lack of motivation. Didactics discussed about the time to start learning Polish, goals and methods of teaching, the program and the role of parents. The main goal of emigration education was to teach children respect for the Polish language and Polish culture. Difficulties have been overcome, as evidenced by contemporary Polonia, who educates children in Polish Saturday schools and PUNO, and constantly maintains a lively contact with the homeland.
\end{abstract}

Key words: the Second Great Emigration in the UK, national education, didactics of the Polish community

Streszczenie: Tematem artykułu jest druga polska emigracja w Wielkiej Brytanii i wychowanie narodowe młodego pokolenia: zapoznanie z polskimi tradycjami, polską historią i ideą niepodległości. Celem emigrantów było zorganizowanie polskich szkół, w których dzieci uczyłyby się polskiej kultury, języka i literatury. Idea napotykała jednak wiele trudności, np. łączenie nauki w szkole polskiej i szkole angielskiej, złe warunki lokalowe, brak polskich podręczników, wpływ języka angielskiego, wstyd swojego języka, brak motywacji. Dydaktycy dyskutowali o czasie rozpoczęcia nauki języka polskiego, celach i metodach nauczania, programie, o roli rodziców, formie egzaminu z języka polskiego. Głównym celem edukacji emigracyjnej było nauczenie dzieci szacunku do mowy polskiej i polskiej kultury. Trudności zostały pokonane, o czym świadczy współczesna Polonia, która kształci dzieci w Polskich Szkołach Przedmiotów Ojczystych oraz PUNO i cały czas utrzymuje żywy kontakt z ojczyzną.

Słowa kluczowe: Druga Wielka Emigracja w Wielkiej Brytanii, edukacja narodowa, dydaktyka polonijna 
Rozważania na temat edukacji emigracyjnej należałoby zacząć od przypomnienia paru faktów leżących u jej źródeł. W 1945 roku dobiegła końca II wojna światowa, a 5 lipca 1945 roku USA i Wielka Brytania cofnęły uznanie dla rządu Rzeczypospolitej na obczyźnie. Wydarzenia z lat 1939-1945 w Polsce przyczyniły się do powstania Drugiej Wielkiej Emigracji (Wolsza 2010, 265):

Poza granicami kraju, w obawie przed represjami ze strony niemieckiego i sowieckiego okupanta, znalazły się tysiące przedstawicieli elit politycznych, wojskowych, literackich, naukowych, artystycznych, sportowych oraz zwykłych emigrantów. Emigranci kierowali się również zamiarem stworzenia poza krajem struktur rządowych, które byłyby zdolne do kierowania walką zbrojną z wrogami, III Rzeszą i Związkiem Sowieckim w kraju i na frontach na całym świecie (Wolsza 2010, 265-266).

Tadeusz Wolsza podaje, że według badaczy, w 1945 roku poza krajem przebywało 2,4-2,6 mln Polaków (Polskie Siły Zbrojne liczyły w lipcu 1945 r. 228 tys., a w październiku 1945 r. - 250 tys. oficerów i żołnierzy). Największe skupiska Polaków przebywały w USA (emigracja przedwojenna), Związku Sowieckim, Niemczech (około 950 tys. w strefach zachodnich i blisko 750 tys. w strefie sowieckiej), Francji (około 70 tys.), Austrii (około 70 tys.) oraz we Włoszech i w Wielkiej Brytanii (po około 12 tys. cywilów) (Wolsza 2010, 268).

Przedmiotem niniejszego artykułu jest druga polska emigracja w Wielkiej Brytanii oraz jej niepodległościowe idee, wśród których jedną z najważniejszych była edukacja młodego pokolenia w duchu narodowym. Rodzice zdawali sobie sprawę $\mathrm{z}$ faktu, że dzieci wychowywane $\mathrm{w}$ angielskich warunkach kulturowo-społecznych, wśród angielskich rówieśników i w angielskich szkołach niełatwo będzie nauczyć polskości. Edukacja musiała przebiegać wielotorowo oraz dotyczyć polskiej historii, kultury, języka i literatury. Problemowi temu poświęcano wiele uwagi, m. in. na łamach czasopism dydaktycznych, w tym jednego z najpoczytniejszych na terenie Anglii i o znamiennym tytule: „Wychowanie Ojczyste”.

Podkreślano w nim rolę polskiej kultury i znaczenie różnicowania polskich i angielskich tradycji:

Aby dziecko czuło się Polakiem, musi poznać i pokochać swój kraj, musi przede wszystkim żyć w atmosferze polskiego domu i polskich tradycji. (...) Trzeba skrzętnie pielęgnować polskie zwyczaje, święta narodowe, kościelne i obyczajowe. (...) Na Boże Narodzenie nie ubieramy domu kolorowymi papierkami, ale

${ }^{1}$ Zgodnie z postulatami zdających sobie sprawę z potrzeb i problemów nauczycieli uczestników Zjazdu Polskich Nauczycieli Szkół Średnich i Powszechnych w Perth w Szkocji w 1941 r. powołano do życia miesięcznik „Przegląd Pedagogiczny” pod redakcją dr. Mieczysława Pawłowskiego, a w roku 1954 r. w Leeds podczas pierwszej konferencji rejonowej Zarząd Polskiej Macierzy Szkolnej podjął decyzję o wydawaniu „Wychowania Ojczystego” - czasopisma dla nauczycieli Polskich Szkół Przedmiotów Ojczystych w Wielkiej Brytanii. W 1955 r. ukazał się pierwszy numer pisma, który w 1984 r. przekształcono w „Wychowanie i Słowo Ojczyste”, następnie w „Słowo Ojczyste” (ukazujące się do 1991 r.). Redaktorem „Wychowania Ojczystego” w 1955 r. został Michał Goławski. Równie poczytnym czasopismem metodycznym były też „Wiadomości Nauczycielskie”. 
stroimy choinkę ${ }^{2}$ i kładziemy siano pod obrusem - dzielimy się opłatkiem. Z prezentami przybywa św. Mikołaj, a nie wieszamy pończochy nad kominkiem. Obchodzimy imieniny, a nie urodziny, jak to jest w zwyczaju angielskim,

\section{ponieważ jednak}

nasze dzieci będą zapraszane przez kolegów angielskich na urodziny, dlatego nie od rzeczy będzie urządzanie przez nas «Birthday party» z tym jednak, że imieniny pozostaną wielkim świętem rodzinnym. Niejednokrotnie będziemy uchylać drzwi, by ze względu na angielskich kolegów naszych dzieci i zapoznawanie ich ze zwyczajami tego kraju „wpuścić jakiegoś angielskiego intruza w rodzaju np. «Guy Fawkes night»" (Dmowska 1956, 32).

Dzień Guya Fawkesa (ang. Guy Fawkes Day, także Noc Guya Fawkesa - Guy Fawkes Night, Noc Ognisk - Bonfire Night) to angielskie święto ludowe obchodzone hucznie 5 listopada ${ }^{3}$. Tradycją tego dnia jest palenie przez dzieci kukieł wyobrażających Guya Fawkesa, a także pokazy sztucznych ogni oraz festyny (por. Allen 1973). Polska autorka w związku z tym angielskim świętem proponuje, by pomówić wtedy z dziećmi o naszych obyczajach, a w tym konkretnym przypadku np. o lajkoniku, mającym również historyczne podłoże (Dmowska 1956, 32). Zaleca ponadto śpiewanie dzieciom polskich piosenek, które „stanowią przeciwwagę piosence obcej” (Dmowska 1956, 32).

W związku z nadchodzącym millennium chrztu Polski w 1966 roku działacze polonijni zwracali uwagę na konieczność nakłonienia codziennej prasy angielskiej, radia i telewizji, aby w okresie nasilenia obchodów polskich dały temu jakiś wyraz (Goławski 1966, 9), zwłaszcza że poczynione zostały duże przygotowania w tym zakresie „na odcinku szkolnictwa angielskiego" (Goławski 1966, 9), czyli zorganizowano wystawę w Bibliotece Brytyjskiego Ministerstwa Oświaty /Department of Education and Science/ ilustrującą „Education of Poles” i 1000 years of Christianity in Poland, a „Dziennik Polski” rozpoczął cykl artykułów Michała Goławskiego pod tytułem „Polska i Polacy w podręcznikach szkolnych”, aby zwrócić uwage polskich rodziców, czego ich dzieci dowiadują się o Polsce i Polakach w szkole angielskiej i z podręczników angielskich. Podjęto akcję (listy do autorów i wydawców) zmierzającą do sprostowania fałszów czy jaskrawych przemilczeń spraw polskich w następnych wydaniach podręczników angielskich (Goławski 1966, 9) .

${ }^{2}$ Warto nadmienić, że tradycja choinki istnieje w Wielkiej Brytanii od 150 lat, a w Polsce od około lat 100.

3 Święto obchodzone jest w rocznicę wykrycia tzw. spisku prochowego, będącego zamachem na życie króla Anglii i Szkocji Jakuba I Stuarta. Plan zamachu opierał się na wysadzeniu Izby Lordów poprzez użycie beczek wypełnionych prochem. Guy Fawkes, angielski wojskowy, członek grupy katolików, którzy zaplanowali zakończony fiaskiem spisek prochowy z 1605 roku, miał w przebraniu strzec materiałów wybuchowych. Ujęty i skazany na powieszenie, choć był tylko jednym z trzynastu spiskowców, jest dziś najmocniej kojarzony z nieudanym spiskiem. 5 listopada 1605 roku londyńczycy zostali zachęceni, by - jako wyraz radości, że królowi udało się uniknąć śmierci - zapalić ogniska.

4 Tematowi temu poświęciłam osobny artykuł pt. Polska emigracja w Wielkiej Brytanii - obraz Innego w historycznej narracji edukacyjnej (tekst w druku). 
Kroki te podyktowane były troską o wychowanie narodowe wśród obcych, które wobec działań angielskich autorów podręczników było poważnie zagrożone. W związku z tym postulowano też zapoznawanie dzieci z polskimi zabytkami na obczyźnie, jak najczęstsze wprowadzanie ich w polskie środowiska, otaczanie odpowiednim do wieku polskim towarzystwem, udział w polskich uroczystościach - co uznawano za nieodzowne elementy wychowania narodowego (Dmowska 1956, 32).

W naszych warunkach wychowania (...) to najważniejszy problem zachowania polskości, która nie tylko jest istotna ze względów narodowościowych, ale [też rodzinnych] - jak długo dzieci będą mówiły po polsku, tak długo ich stosunek do rodziców będzie nacechowany szacunkiem i poczuciem przynależności rodzinnej (Borzyskowska 1966, 18).

Podejmowane działania były więc nakierowane na kształcenie polskiej tożsamości narodowej wśród angielskiego otoczenia.

Zadanie to dotyczyło już najmłodszych, bowiem praca zawodowa matek poza domem stwarzała wielkie trudności w realizowaniu planów wychowawczych i nierzadko zmuszała rodziców do oddania dzieci na całe dnie do angielskich przedszkoli, a to stanowiło poważne niebezpieczeństwo dla polskości dziecka. Uważano więc, że polskie przedszkola są jedynym ratunkiem dla wielu rodziców i sprawę całodziennych przedszkoli uznano za kwestię o pierwszorzędnym znaczeniu, która nie może być niedoceniana przez zbiorowy wysiłek społeczny (Dmowska 1956, 32-33):

zorganizowanie przedszkola jest niezwykle ważne, bo taka zbiorowa opieka - pełna pięknych piosenek i rzewnych wierszyków - w myśl zasady: uczyć się bawiąc i bawić się ucząc, zapada głęboko w umyśle malutkich główek, gdzie te skarby rodzime pozostaną aż do grobowej deski (Borzyskowska 1966, 19).

Podobnie „decydując się na oddanie dziecka do szkoły internatowej, musimy wybrać szkołę polską, bo tylko ta daje gwarancje, że nasze dziecko się nie wynarodowi" (Dmowska 1956, 33), tym bardziej że obca szkoła, według polskich dydaktyków, pochłaniała większość energii dziecka, ugruntowywała i rozwijała obcy język, a polski - w zależności od postawy rodziców i wysiłków sobotniej szkoły ojczystej - rozwijał się bardzo powoli, stał w miejscu lub się cofał (Bogusławska 1958, 35).

Problem tkwił w tym, że „Dziecko angielskie ma jedną szkołę - dziecko polskie ma dwie szkoły" (Piałucha 1956, 40), bowiem przez pięć dni w tygodniku uczęszczało do szkoły angielskiej i tylko jeden dzień - sobotę - poświęcało na naukę w szkole polskiej. Poza tym polskie szkoły sobotnie nie były przedmiotem zainteresowań, troski i opieki całego społeczeństwa. Istniały na marginesie życia, poza nawiasem i w obcym kraju, mieściły się przeważnie kątem w obcych szkołach, bez pewności jutra, trwałego zaplecza i trwałych funduszów. Świadczyły swoim istnieniem o niezłomnej woli społeczeństwa polskiego na emigracji pozostania nadal polskim i utrzymania młodego pokolenia przy polskości i dla Polski (Gołowczyńska 1967, 9-10). Podkreślano, że patriotyzm jest uczuciem nabytym i dopiero przez 
poznanie historii i geografii Polski można w szkole ojczystej stopniowo dążyć do zaszczepienia tego uczucia (Duszowa 1956, 8), zwłaszcza że polska szkoła kładzie główny nacisk na wychowanie w sensie utrwalania i rozszerzania polskości dziecka i do tego celu służy właśnie nauczanie przedmiotów ojczystych (Borzyskowska 1966, 17). Dlatego właśnie starano się zgromadzić jak najwięcej polskich dzieci, aby uczyć mowy polskiej, podawać elementarne wiadomości z geografii i historii ojczystej, budzić i utwierdzać poczucie przynależności narodowej oraz pogłębiać dostęp do kultury ojczystej (Stanecki 1968, 17). Szkoła angielska zajmowała się ogólnym wykształceniem.

Nauka w szkole sobotniej napotykała jednak na szereg trudności, które wynikały m.in. „z różnicy stopnia opanowania języka polskiego w poszczególnych grupach, niemożności zebrania uczniów tej samej kategorii wieku w jednej klasie, jakości pomocy - lub jej braku ze strony domu rodzinnego (małżeństwa mieszane itd.)" (Stanecki 1968, 17).

Ponadto nauka języka polskiego nie była w Anglii zakazana, odpadał więc aspekt przygody i bohaterstwa. Nie bez znaczenia był też fakt, że szkoła angielska wyposażona była znacznie lepiej w pomoce naukowe niż polska, dlatego uczenie się w niej stawało się przyjemnością. Jak stwierdzono, były to „«pasywa» dziecka przychodzącego do szkoły polskiej w sobotę" (Duszowa 1956, 9).

Szkoła angielska wypełniała po brzegi pięć dni w tygodniu, a swoim rzeczowym podejściem do oceny postępów w nauce oraz powagą i życzliwą tolerancją dla kultury „foreignerów” działała pociągająco. Była też wysoce atrakcyjna, albowiem: wyświetlała przeźrocza, pokazywała różne eksponaty, rozporządzała bogatą, ilustrowaną biblioteką, organizowała wycieczki, zabawy, rozrywki, konkursy, stwarzała szlachetne współzawodnictwo, dostarczała sportowych emocji poprzez gry, pływalnię i wyścigi.

Dawała wszechstronne wiadomości i wymagała wytężonej pracy, bowiem świadectwa z ukończenia szkoły nie można było uzyskać, jeżeli egzaminy nie były zdane na odpowiednim poziomie, co wiązało się z kolejną istotną dla młodych ludzi kwestią - otwierała drzwi do wyższych uczelni, co u ambitnej młodzieży odgrywało poważną rolę (Borzyskowska 1966, 19).

Fakt, że angielskie dzieci miały całą sobotę do swojej wyłącznej dyspozycji, u ich polskich kolegów wywoływał zazdrość i wzbudzał negatywne nastawienie do polskiej szkoły, która ograniczała im wypoczynek i zasłużone odprężenie po całotygodniowej pracy umysłowej. Dydaktycy polonijni podkreślali jednak, że „nie należy obrzydzać tej angielskiej instytucji, ale jeszcze większą trzeba zwracać czujną uwagę, ażeby jakimś nietaktem nie podsycać u dziecka niechęci do polskiej szkoły" (Borzyskowska 1966, 19).

Polskie rodziny w uczęszczaniu dzieci do szkoły angielskiej dopatrywały się również niebezpieczeństw rodzaju wychowawczego, ponieważ 
przebywanie dziecka przez 5 dni w tygodniu, a także pozostałe 2 w dużej mierze w obcym środowisku i pod oddziaływaniem różnych niejednokrotnie nam obcych poglądów i celów urabia w pewnym kierunku nasze dziecko. Dziecko nasiąka tymi warunkami i oddziaływaniem. Potrzebna jest więc kontrola, krytycyzm i czuwanie. Radio z podniecającymi historyjkami, telewizja i kino również «stroją» struny dusz naszych dzieci na modłę i potrzebę kraju, w którym przebywamy (Nowak 1956, 11).

Podobne zastrzeżenia budził inny niż w polskiej szkole rodzaj organizacji szkoły angielskiej oraz odmienne metody nauczania, które stwarzały inne warunki i przyzwyczajenia polskich dzieci, co nie zawsze było do zaakceptowania przez polską szkołę i rodziło konflikty. Szansą na ich rozładowanie była świadomość tych faktów, która mogła spowodować odmienną ocenę zachowania się dziecka i pomóc w zrozumieniu, że dziecko w tym świetle nie popełniło żadnego przewinienia (Nowak 1956, 11), np. „swobodniejsza metoda podejścia do dzieci w szkołach angielskich powoduje w naszych dzieciach pewną buńczuczność; samowolę, pewien upór, czy spoufalanie się ze starszymi” (Nowak 1956, 10), „brak manier (...) który można zauważyć u angielskich dzieci (ręce w kieszeniach, przeciąganie się, piski, gwizdy, złe zachowanie się w autobusach itp.)" (Nowak 1956, 10).

Wiedza rodziców i nauczycieli mogła stać się swoistym wychowawczym buforem - umożliwiała dyskretną korektę zachowań bez szukania winnych zaistniałych sytuacji.

Podobnie przestrzegano również przez zbyt ostrymi uwagami za rozmowy angielskie, ponieważ powodowało to niekorzystne nastawienie dziecka do polskości. Psychologiczne czynniki, takie jak nastawienie, motywacje czy zainteresowania, to niezwykle ważne elementy edukacji, które często decydują o jej efektach. Dowiodły tego też obserwacje zachowań dzieci w polskich szkołach:

Jedne chętnie uczęszczają do polskiej szkoły (...) ciekawe wszystkiego co polskie, chętne do nauki. Inne przychodzą pod naciskiem rodziców - traktują szkołę sobotnią jako dodatkowy ciężar do całotygodniowej nauki w szkole angielskiej. Stoją na uboczu spraw szkolnych, nie dają się wciągnąć w krąg zainteresowań ogólnych, spychają lekcje od niechcenia - lub w ogóle ich nie odrabiają. Czują się pokrzywdzone, że muszą się uczyć języka i przedmiotów, które przecież, w ich mniemaniu, praktycznie nic im nie dają. Niektóre z nich po pewnym czasie zmieniają swój stosunek - tracą sztywność i obcość, dołączają do aktywnej gromadki - inne do końca zachowują swój negatywny stosunek i czekają tylko, kiedy nareszcie skończą się lekcje (Gołowczyńska 1967, 10).

Dydaktycy i rodzice, mając świadomość złożoności sytuacji edukacyjnej polskich dzieci na emigracji, stwierdzali: „Niebezpieczeństwo wynarodowienia naszych dzieci jest ogromne i obrona ich przeciw temu jest naszym ostatnim szańcem" (Borzyskowska 1966, 19).

Szukając przekonujących argumentów, czyli pozytywów, które zmotywowałyby dzieci do nauki w sobotnich szkołach, uznano, że należy wykazać, „jakie duże korzyści daje wielojęzyczność” (Borzyskowska 1966, 19): 
„dzieci dwujęzyczne uczą się w szkole lepiej niż te, które znają tylko jeden język. W wielu szkołach angielskich mówią o tym dyrektorzy i zachęcają dzieci polskie (o gorzka ironio!) do nauki polskiego" (Płoska 1969, 11). Problem jednak polegał na tym, że układając plan pracy w polskiej szkole, zapominano, „jak uczniowie są ekspansowani w szkole angielskiej pod względem ich wysiłku umysłowego, fizycznego i czasowego. Ta jest właściwą szkołą, a szkoła polska dodatkiem i to obciążającym" (Piałucha 1968, 5), dlatego wszelkie argumenty przemawiające za dodatkowej nauką były (i niestety nadal są) trudne do przeforsowania.

Jakby tego było mało, szwankowała organizacja szkół polskich, które w porównaniu ze szkołami angielskimi były po prostu gorsze: „warunki na ogół ciężkie (z wyjątkami), niewystarczająca ilość sal szkolnych i nauczycieli, stłoczenie różnych roczników $\mathrm{w}$ jednym zespole, nauka po szatniach, kuchniach, brak pomocy szkolnych" (Nowak 1956, 11). Nietrudno się domyślić, że skutki nie były korzystne dla rodzimej edukacji, np. lepszy system edukacyjny szkoły angielskiej stwarzał „podatne warunki do podrywania karności w szkole polskiej" (Nowak 1956, 11). Zdawano sobie sprawę z tego, że urządzenie polskiej szkoły sobotniej powinno różnić się od urządzenia normalnej szkoły. Postulowano dostosowanie szkoły pod wieloma względami, głównie - lokalowymi, programowymi i metodycznymi. Nie zakładano od razu przystosowywania całych budynków, ale przynajmniej pojedynczych lokali, które powinny

mieć charakter skromnej, lecz schludnej świetlicy zaopatrzonej w różnego rodzaju urządzenia rozrywkowe, dostosowane do wieku i zainteresowań dziecka. Na pierwszym miejscu w programie pracy winny figurować takie przedmioty jak śpiew, gry i zabawy, tańce indywidualne i zbiorowe, inscenizacje, bajki, opowiadanie i czytanie przez nauczyciela, układanki, rysunki i malowanie itd. (...) Długie i nudne lekcje gramatyki, ortografii, egzaminowanie dzieci ze szczegółów historycznych, wprowadzanie elementów geografii matematycznej, lekcje rachunków (...) powinny być usunięte z programu przedmiotów ojczystych dla dzieci na poziomie elementarnym (Piałucha 1956, 40).

Podkreślano wagę systematycznego prowadzenia nauki języka polskiego, natomiast co do innych przedmiotów, np. historii, uważano, że powinny być „rzutami fragmentarycznymi, w formie zwięzłej i interesującej” (Piałucha 1956, 40), ale jednocześnie „historia w nauczaniu naszym musi być żywa. Broń Boże nie nudna. Pojęto to doskonale ożywiając nauczanie wzrokowo dobrą, żywą ilustracją, a znakomitym pomysłem są albumy szkolne (historyczne)" (Kukiel 1968, 9), bowiem - jak podkreślano - trzeba „Budzić myśli” (Kukiel 1968, 9). Postulat ten był zbieżny z propozycją innej autorki, A. Falkiewiczowej, która tłumaczyła:

gdyby te pogadanki ilustrowało się pięknymi, barwnymi obrazami to wiadomo, że pobudziłyby one ich wyobraźnię żywiej, niż samo słowo. Piękno polskiej przyrody, zobrazowanie tysiącletniej kultury i bohaterskiej przeszłości, pokazałoby im równorzędność, a w wielu wypadkach wyższość Polski nad innymi krajami (Falkiewiczowa 1960, 3). 
Na stawiane przez nauczycieli i rodziców pytanie: Jedna czy dwie szkoły? - dydaktycy stwierdzali - „jedna szkoła i to angielska. Druga nie jest bowiem szkołą w ścisłym znaczeniu, lecz ośrodkiem pełnym atmosfery ojczystej, w którym młodzież nasza przez rozrywkę i pracę utrwala w sobie polskość” (Piałucha 1956, 40), ale nie jest „«szkółką». Istota leży w tym nie «ile» $\mathrm{i}$ «czego», ale jak uczymy i z jakim nastawieniem oraz czy posiadamy mocny i zdecydowany kierunek wychowawczy (Duszowa 1956, 11).

W określeniu owego kierunku zasadniczą rolę odgrywali i nadal odgrywają - rodzice, bowiem jeśli chcemy, aby dziecko mówiło poprawną polszczyzną, to oni muszą dołożyć wszelkich starań do zachowania czystości mowy ojczystej. Tymczasem niektórym rodzicom, którzy opuścili kraj, mając kilka lat, byli oderwani od polskich rodzin, kształcili się w Anglii i obracali się $\mathrm{w}$ angielskim środowisku - poprawne mówienie $\mathrm{w}$ języku ojczystym sprawia duże trudności, które trzeba pokonywać, ponieważ „Trudno dziecku przestrzegać czystości mowy polskiej, jeśli matka idzie na «schopping», daje dziecku «sixa» na «lolipop», dziecko «bierze bus», a ojciec jedzie «undergroundem»" (Dmowska 1956, 32). Bywają też rodzice przeciwni dwujęzyczności swoich dzieci. Uważają, że można zostawić język ojczysty „na potem”, bowiem początkowo dziecko powinno się skoncentrować na jednym, tj. angielskim, zaś nauka polskiego będzie mu w tym przeszkadzać. Irena Borzyskowska stwierdziła kategorycznie: „niepowetowany błąd czyni ten, kto odkłada naukę języka ojczystego na później, bo nie da się naprawić straconej bezpowrotnie okazji, kiedy ta możność nie tylko mówienia, ale nawet myślenia po polsku zostanie zmarnowana" (Borzyskowska 1966, 19). Podobnie ocenia taką strategię autor ciekawego artykułu na temat nauczania dwujęzycznego, według którego są to może najlepsze pobudki rodzicielskie, ale na pewno nie narodowe, zwłaszcza że jego własne doświadczenia z dzieciństwa przeczą takiej kolejności nauki języka:

Rodzeństwo i ja urodziliśmy się w Rosji. Poza domem, w zabawie z dziećmi Rosjan w szkole rosyjskiej (bo innej nie było w naszej miejscowości) istniał dla nas tylko rosyjski język, ale w gronie rodziny, gdy któreś z nas wtrąciło rosyjskie słowo albo chociaż tylko rusycyzm rodzice nas «nie rozumieli» (nie tak jak tutaj obserwuję - polscy rodzice doskonale rozumieją «slajdy, ajskrymy, pikczersy» itp. wyrażenia swoich dzieci). (...) Przestrzeganie czystości mowy ojczystej i lekcje polskiego, ani trochę nie przeszkodziły nam w osiągnięciu wcale niezłych postępów w szkole rosyjskiej (S.J. 1956, 37).

$\mathrm{Na}$ jeszcze inne niebezpieczeństwo rodzicielskiej edukacji językowej zwróciła uwagę przywoływana przed chwilą Irena Borzyskowska. Według niej równie wielką szkodę

wyrządza wstyd swojego języka wobec obcych i wtrącanie wyrazów angielskich, które najczęściej wymawiamy błędnie i w nieodpowiednim miejscu. Dziecko nabiera mylnego mniemania, że język polski jest ubogi i potrzebuje zapożyczonych słów, a zły akcent podrywa autorytet i tylko ośmiesza tak rodziców jak i wychowawców (Borzyskowska 1966, 19). 
Autorka dotknęła tutaj innego niezwykle istotnego aspektu życia Polonii - odczuwanego przez wielu emigrantów kompleksu niższości, z którym starano się walczyć, podnosząc ich samoocenę i kształcąc świadomość narodową. Halina Dmowska tłumaczyła:

Zupełnie nieznane jest mi zjawisko kompleksu niższości wobec Anglików. Temat ten często przewija się w troskach rodziców o wychowanie dzieci. Dopatruję się w tym kardynalnej winy samych rodziców, prawdopodobnie posiadających taki uraz. Z wielką przykrością słyszę podczas swoich przejazdów, jak polscy rodzice kaleczonym angielskim językiem rozmawiają ze swymi polskimi dziećmi lub używając języka ojczystego, ściszają mowę do szeptu. Cała nasza akcja wychowawcza, zmierzająca do wyrobienia poczucia przynależności narodowej, ma w wyniku wzbudzić dumę narodową, która też zapobiegnie tak zwanemu kompleksowi niższości wobec obcych (Dmowska 1956, 33).

Czasem źródłem takich sytuacji byli właśnie sami „obcy”. Jeden z przywoływanych już autorów tekstów w „Wychowaniu Ojczystym” dzielił się z czytelnikami swoimi refleksjami:

zrastaniu moich dzieci towarzyszyły życzliwe uwagi przyjaciół Anglików: «Powinniście rozmawiać z dziećmi po angielsku, będzie im znacznie łatwiej, gdy pójdą do szkoły». Odpowiadaliśmy im z żoną (...): «Polacy urodzeni pod zaborami, czy zgoła poza Polską, wychowani byli w mowie i w duchu polskim, a język urzędowy przyszedł sam». Gdyby obecnie dzieci polskie uczyły się początków języka angielskiego od swych rodziców, to wtedy naprawdę miałyby trudności w angielskiej szkole. Angielskiej mowy nauczą się wśród pięćdziesięciu milionów Brytyjczyków, polskiej - często tylko od swych dwojga rodziców (S.J. 1956, 37).

Kolejnym problemem edukacyjnym - obok nauki mówienia po polsku, był czas rozpoczęcia nauczania czytania i pisania po polsku. Dydaktycy byli zdania, że można rozpocząć ją przed oddaniem do szkoły angielskiej, choć niekoniecznie w formie systematycznych lekcji, lecz ,jakby mimochodem". Halina Dmowska dowodziła, że jej dzieciom umiejętność czytania po polsku nie tylko nie zaszkodziła w czytaniu po angielsku, lecz nawet pomogła, bowiem syn mając osiem i pół lat, czytał płynnie po angielsku i równie biegle po polsku (Dmowska 1956, 32).

$\mathrm{Na}$ późniejszym etapie edukacji językowej zalecano przedstawianie uczniom

zestawień zasad języka polskiego i obcego, kraju, w którym uczymy, np.

dźwięki, które są podobno takie trudne spotykamy i w angielskim:

$\dot{z}$ (ż i rz) ang. jury, measure

sz - marsh, shame, show

cz - march, church, chair

dż - judge, smudge, grange

ang. the i a jako przedimki, franc. le, la, les, niem. der, die, das.

(...) Takie porównania $\mathrm{z}$ innymi językami zainteresują dzieci i zachęcą do pracy

(Płoska 1969, 12). 
Duszowa, analizując kwestie programowe, zauważyła, że „naszym obowiązkiem będzie: wypełnić luki i położyć akcenty na działy, z którymi się uczeń w szkole angielskiej nie zetknie, lub które wymagają dodatkowych ćwiczeń pod kierunkiem nauczyciela" - Polaka (Duszowa 1956, 11). Do tych newralgicznych działów należały:

wymowa polskich liter, i uzupełnienie abecadła angielskiego o litery czysto polskie (znaki dwuliterowe jak rz, cz, ch oraz zmiękczenia ń, ć ), nazwy polskich znaków pisarskich - przedstawienie pojęć ogólnych z historii i geografii, nawet religii (benediction zamiast błogosławieństwo) (...) zanim się stopniowo i systematycznie do tego dojdzie. Uniknie się w ten sposób utrwalenia błędów językowych i zapobiegnie zupełnie słusznemu usprawiedliwieniu dziecka, karconemu za żargon polsko-angielski - «ja nie wiem, jak to powiedzieć po polsku» (Duszowa 1956, 11).

W związku z dwutorowością nauki polskich dzieci na życzenie rodziców w klasach gimnazjalnych w roku 1961 w szkołach sobotnich wprowadzono ćwiczenia polsko-angielskie realizowane według planu:

1. pogadanka o grupach językowych, zasadniczych różnicach oraz wspólnocie, jeśli chodzi o przyswojenie znacznej liczby słów z łaciny;

2. ustne i piśmienne przekłady $\mathrm{w}$ klasie, ilustrowane przykładami prawidłowej budowy zdania tak w przekładzie $\mathrm{z}$ angielskiego na polski, jak i odwrotnie;

3. przysłowia i idiomy angielskie oraz ich polskie odpowiedniki;

4. pisanie listów (4 wzory) po angielsku i po polsku;

5. zadania domowe i klasowe (przekład tekstu) (Goławski 1961, 17).

Natomiast w ramach edukacji literackiej zalecano, by

zwrócić uwagę na to, że w literaturze angielskiej większość porównań i przenośni powstała na tle żagla i morza: to sail majestically, to weather a difficulty, w polskim natomiast nasi pisarze i miliony bezimiennych twórców języka, oparły się na życiu rolniczym i gospodarce rolnej: bruździć, orać ciężko, młócić jak cepem (Płoska 1969, 25).

Egzamin z języka polskiego już na poziomie niższym (ordinary level) opierał się na znajomości dwu języków i przebiegał w dwu etapach:

Egzamin piśmienny (3 godziny)

1. tłumaczenie $\mathrm{z}$ polskiego na angielski,

2. tłumaczenie $\mathrm{z}$ angielskiego na polski,

3. krótkie wypracowanie w języku polskim na temat jeden spośród 4 zaproponowanych,

4. dyktando w języku polskim.

Egzamin ustny

Przeczytanie około 10 wierszy tekstu, wybranego przez egzaminatora. Uczeń będzie mógł zastanowić się około 2-3 minut nad przeczytanym tekstem. Rozmowa egzaminatora z uczniem na temat przeczytanego ustępu (Jak zgłosić... 1961, 19).

„Tak ujęte wymagania oraz przykłady tematów i tekstów egzaminacyjnych nie budzą wątpliwości, że uczeń musi dobrze znać język polski, jeśli chce zdać ten egzamin" (Jak zgłosić... 1961, 19). 
Kończąc nasze rozważania na temat trudnych początków emigracyjnej edukacji, przywołajmy jeszcze opinię Zofii Szczepankowskiej, która zwracała uwagę na niebezpieczeństwo wynarodowienia spowodowane brakiem równowagi pomiędzy wiedzą z historii, literatury i ogólnego całokształtu kultury angielskiej a odpowiednimi wiadomościami o Polsce otrzymywanymi w szkole sobotniej - „siłą rzeczy w szczupłym zakresie (2-3 godziny tygodniowo!)", niebezpieczeństwo prowadzące do nabrania przez młodzież polską „mylnego wyobrażenia o kulturze polskiej jako bezwzględnie niższej, nie mogącej jej imponować i tym bardziej zapragnie nie tylko «włączyć się» w społeczeństwo brytyjskie, ale i z nim duchowo się zespolić" (Szczepankowska 1959, 12). Ten lęk towarzyszył wielu polskim rodzicom i nauczycielom, z pewnością też nie był obcy działaczom Polskiej Macierzy Szkolnej, organizacji cieszącej się

uznaniem i szacunkiem za pracę, jaka wzbogaca nasze życie społeczne na emigracji, na niezwykle ważnym odcinku - na odcinku szkolnym, gdzie rzeźbi się duszę naszej młodzieży, gdzie kształci się jej charakter, pogłębia religijność, wpaja miłość ojczyzny poprzez przywiązanie do mowy polskiej, do naszych dziejów ojczystych i całej naszej tysiącletniej kultury (Hęciak 1966, 4).

Zadanie zostało zrealizowane wzorowo, o czym świadczy współczesna Polonia w Wielkiej Brytanii - związana z ojczyzną, dbająca o polską kulturę i narodową tożsamość, szanująca polskie tradycje, ceniąca polską historię, kształcąca swoje dzieci w Polskich Szkołach Przedmiotów Ojczystych i Polskim Uniwersytecie na Obczyźnie, kochająca polski język i polską literaturę - pamiętająca, że mimo iż żyje wśród Innych, nadal jest żywą cząstką Polskiego Narodu.

\section{Bibliografia:}

Allen K., 1973, The Story of Gunpowder, Wayland.

Bogusławska Anna, 1958, Dzieci dwujęzyczne, „Wychowanie Ojczyste” I-II, z. 1, s. 35-37.

Borzyskowska Irena, 1966, Wychowanie i szkoła, „Wychowanie Ojczyste” III-IV, z. $2 / 63$, s. $17-20$.

Dmowska Halina, 1956, Sprzyjające i nieprzychylne okoliczności pracy wychowawczej rodziców, „Wychowanie Ojczyste” V-VI, z. 4, s. 29-33.

Duszowa Maria, 1956, Specyficzny charakter „szkoły ojczystej”, „Wychowanie Ojczyste" V-VI, z. 4, s.8-11.

Falkiewiczowa A., 1960, Jak uczę dzieci z mał̇̇eństw mieszanych, „Wychowanie Ojczyste” IX-X, z. 5/30, s. 3-6.

Goławski Michał, 1966, Sprawozdanie Wydziału Szkolno-Wydawniczego, „Wychowanie Ojczyste” III-IV, z. 2/63, s. 7-10.

Goławski Michał, 1961, Z moich doświadczeń, „Wychowanie Ojczyste” I-II, z. $1 / 32$, s. $17-18$. 
Gołowczyńska T., 1967, Ocena postępów w szkole, „Wychowanie Ojczyste” V-VI, z. 3/70, s. 9-12.

Hęciak Paweł, 1966, VII Walny Zjazd Polskiej Macierzy Szkolnej Zagranica. Artykuł Prezesa Zjednoczenia Polskiego, „Wychowanie Ojczyste” III-IV 1966, z. $2 / 63$, s. 4 .

Jak zgłosić dziecko polskie do egzaminu z języka polskiego na „General Certificate of Education”, 1961, „Wychowanie Ojczyste” I-II, z. 1/32, s. 18-19.

Kukiel Marian, 1968, Uwagi o nauczaniu historii na emigracji, „Wychowanie Ojczyste" I-III, z. 1/74, s. 8-16.

Nowak Stanisław, 1956, Karność w domu i w szkole - cz. I (Czynniki wpływajace na karność dziecka), „Wychowanie Ojczyste” XI-XII, z. 7, s. 9-13.

Piałucha Piotr, 1956, Jedna czy dwie szkoły?, „Wychowanie Ojczyste” VII-VIII, z. 5, s. 39-41.

Piałucha Piotr, 1968, Nauczanie historii, „Wychowanie Ojczyste” X-XII, z. 4/77, s. 2-5.

Płoska Janina, 1969, Nauczanie języka polskiego na obczyźnie, „Wychowanie Ojczyste" VI-IX, z. 3/80, s. 11-12, 25.

S.J., 1956, Nauczanie dwujęzyczne, „Wychowanie Ojczyste” V-VI, z. 4, s. 37-38.

Stanecki Czesław, 1968, Ocena postępów w szkole ojczystej, „Wychowanie Ojczyste" IV-V, z. 2/75, s. 16-18.

Wolsza Tadeusz, 2010, Polacy na emigracji 1945-1956, w: Persak K., Machcewicz P. (red.), Polski wiek XX: PRL od lipca 1944 do grudnia 1970, Warszawa, s. 263-293.

\section{O Autorce:}

Danuta Jastrzębska-Golonka - doktor habilitowany nauk humanistycznych w zakresie językoznawstwa; prof. nadzw., kierownik Zakładu Dydaktyki Literatury i Języka Polskiego Uniwersytetu Kazimierza Wielkiego w Bydgoszczy. Opublikowała szereg artykułów z zakresu m.in. językoznawstwa stosowanego, historii dydaktyki polskiej, dydaktyki literatury, języka polskiego i historii, polskiej edukacji emigracyjnej, problematyki nauczania i funkcjonowania dzieci niepełnosprawnych, języka młodzieży szkolnej literatury dla dzieci i młodzieży. Autorka monografii: Fonetyka wczoraj i dziś. Ewolucja wiedzy fonetycznej w opracowaniach i podręcznikach gramatyki dla szkół średnich okresu międzywojennego na tle historii nauczania języka polskiego (Bydgoszcz 2004) oraz Konceptualizacja świata przedstawionego $w$ języku najnowszego przekładu tekstów Hansa Christiana Andersena (Bydgoszcz 2011). Uczestniczyła w kilkudziesięciu konferencjach naukowych na terenie Polski oraz poza granicami kraju. 